\title{
KANDUNGAN NUTRISI WHEY HASIL SAMPINGAN DARI DANGKE
}

\author{
Rajmi Faridah \\ Program Studi Peternakan, STIP Muhammadiyah Sinjai \\ JI. Teuku Umar No. 8 Sinjai \\ e-mail: rajmifaridah@gmail,com
}

\begin{abstract}
Abstrak
Proses pembuatan dangke menghasilkan hasil sampingan berupa whey. Whey dangke dapat diolah menjadi berbagai produk karena whey mengandung nutrisi. Tujuan penelitian yaitu untuk menganalisis jenis kandungan nutrisi yang terkandung dalam whey serta persentase dari kandungan nutrisi tersebut. Dangke diolah dari susu sapi yang dipanaskan dengan api kecil sampai hampir mendidih, kemudian ditambahkan koagulan berupa papain murni. Lactoscan digunakan untuk menganalisis lemak, total padatan, berat jenis, protein whey. Whey dangke mengandung komponen nutrisi berupa lemak $0.3 \%$, laktosa $5.49 \%$ dan protein $0.36 \%$.
\end{abstract}

Kata kunci : nutrisi, whey, dangke.

\section{PENDAHULUAN}

Dangke adalah produk olahan khas kabupaten Enrekang yang merupakan sejenis keju lunak dari susu sapi atau kerbau dan dihasilkan tanpa proses fermentasi. Proses pembuatan dangke menghasilkan hasil sampingan berupa whey. Jumlah whey dangke sekitar 3.600 liter perhari dan umumnya dibuang begitu saja (Fatma et al., 2012).

Whey dangke dapat diolah menjadi berbagai produk yang salah satunya menjadi produk minuman fermentasi. Produk tersebut sangat diminati masyarakat saat ini dan mempunyai nilai jual yang baik (GallardoEscamila dkk., 2007).

Komponen nutrisi whey dangke juga dapat dimanfaatkan oleh bakteri sebagai sumber nutrisi pertumbuhan. Komponen bioaktif whey menyebabkan produk fermentasi memiliki aktivitas antibakteri patogen, sehingga dapat lebih meningkat dengan penggunaan probiotik Lactobacillus acidophilus (Almeida, 2008).

Tujuan penelitian yaitu untuk menganalisis jenis kandungan nutrisi yang terkandung dalam whey serta persentase dari kandungan nutrisi tersebut.

\section{Metode Pembuatan Whey Dangke}

Dangke diolah dari susu sapi yang dipanaskan dengan api kecil sampai hampir mendidih, kemudian ditambahkan koagulan berupa papain murni $0.3 \%$ pada suhu $80{ }^{\circ} \mathrm{C}$, kemudian ditambahkan garam sebanyak $0.4 \%$ (Mukhlisah 2017). Setelah terjadi pemisahan antara gumpalan dan cairan berwarna kuning, gumpalan tersebut dimasukkan ke dalam cetakan khusus yang terbuat dari tempurung kelapa (bagian ujungnya dilubangi untuk jalan ke luar cairan) dan whey ditampung untuk penelitian tahap selanjutnya (Marzoeki 1978).

\section{Uji Nutrisi Whey Dangke (Kabui et al. 2014)}

Lactoscan digunakan untuk menganalisis lemak, total padatan, berat jenis, protein, titik beku dan penambahan air. Sampel di masukkan dalam gelas $\pm 20 \mathrm{~mL}$, kemudian Laktoscan di hidupkan dengan di aliri listrik. Sampel dimasukkan pada tempat analisis. Prinsip kerja lactoscan yaitu sampel masuk ke dalam alat laktoscan, lalu melewati pancaran gelombang bunyi dan sampel akan keluar lagi. Hasil analisis 
keluar setelah sampel melewati gelombang bunyi.

\section{PEMBAHASAN}

Whey susu merupakan serum atau bagian air dari susu yang tersisa setelah pemisahan curd yang merupakan hasil koagulasi protein susu dengan penambahan asam atau enzim proteolitik (Vinderola et al. 2000). Salah satu hasil olahan susu yang menghasilkan whey yaitu proses pembuatan dangke. Kandungan nutrisi whey dangke dapat dilihat pada Tabel 1.

Tabel 1. Komponen Nutrisi Whey Dangke

\begin{tabular}{l|c}
\hline \multicolumn{1}{c|}{ Komponen } & Nilai \\
\hline Padatan (\%) & 7.55 \\
Lemak (\%) & 0.83 \\
Laktosa (\%) & 5.49 \\
Protein (\%) & 0.36 \\
$\mathrm{pH}$ & 6.40 \\
\hline
\end{tabular}

Nilai komponen padatan whey dangke yaitu $7.55 \%$ (Tabel 1). Hasil tersebut sejalan dengan penelitian Panesar et al. (2007) bahwa total padatan yang dihasilkan dari whey keju manis dan asam yaitu sebesar $6.3-7 \%$. Lemak dari whey dangke yaitu sebesar $0.83 \%$. Hasil tersebut berbeda dengan beberapa penelitian sebelumnya. Fatma et al. (2012) mengemukakan bahwa whey dangke menghasilkan lemak sebesar $0.2 \%$ (Tabel 1). Penelitian yang dilakukan oleh Almeida et al. (2008) menggunakan whey keju menghasilkan lemak sebesar $0.5 \%$. Perbedaan kandungan nutrisi whey yang dihasilkan dalam pembuatan keju disebabkan karena komposisi susu, proses pembuatan, dan bahan penggumpal yang digunakan tidak sama (Altiok 2004).

Laktosa yang dihasilkan dari whey dangke yaitu sebesar $5.49 \%$ (Tabel 1). Hasil tersebut sejalan dengan hasil penelitian Fatma et al. (2013) bahwa kandungan laktosa whey dangke yaitu sebesar 5.08\%. Panesar et al. (2007) menyatakan bahwa komponen laktosa dalam whey berpotensi dimanfaatkan oleh BAL untuk pertumbuhannya. Kandungan protein dalam whey dangke yaitu $0.36 \%$. Hasil tersebut sangat rendah dibandingkan dengan beberapa penelitian sebelumnya. Hal tersebut mungkin disebabkan karena dalam proses pembuatan dangke dengan menggunakan papain murni, protein dari susu yang digunakan sebesar $2.76 \%$ hampir terkoagulasi sempurna sehingga protein whey sangat rendah.

Protein whey yang dihasilkan umumnya berkisar 0.6-1\% (Fatma et al. 2013; Panesar et al. 2007; Gallardo et al. 2005). Nilai pH dari whey dangke yaitu 6.40 (Tabel 1), nilai tersebut sejalaN dengan penelitian yang telah dikemukakan oleh Fatma et al. (2013) bahwa nilai pH whey dangke yaitu sebesar 6. 31 . Gallardo et al. (2005) mengemukakan bahwa nilai $\mathrm{pH}$ dari berbagai macam whey berbedabeda tergantung pada jenis dan konsentasi bahan penggumpal, perlakuan pemisahan curd dengan whey, dan pemisahan sisa lemak dari whey.

\section{KESIMPULAN}

Whey dangke mengandung komponen nutrisi berupa lemak, laktosa dan protein.

\section{DAFTAR PUSTAKA}

Almeida K, Tamime A, Oliveira M. 2008. Acidification rates of probiotic bacteria in Minas frescal cheese whey. LWT Food Sci Technol. 41(2):311-316.

Altiok, D. 2004. Kinetic modeling of lactid acid production from whey. Dissertation Department Food Engineering Izmir Institute of Technology, Turkey. [internet]. Tersedia pada: http://www.library.iyte.edu.tr/tezler/master/ gidahu/T000471.pdf. 
Fatma, Soeparno S, Nurliyani N, Hidayat C, Taufik M. 2013. Karakteristik Whey Limbah Dangke dan Potensinya Sebagai Produk Minuman dengan Menggunakan Lactobacillus acidophilus Fncc 0051 (Characteristics of Whey from Dangke Waste and Its Potential as Beverage Product by using Lactobacillus acidophilus FNCC 0051). J Agritech. 32(04).

Gallardo EFJ, Kelly AL, Delahunty CM. 2005. Sensory characteristics and related volatile flavor compound of different types of whey. J Dairy Scien 88: 2689-2699.

Kabui KK, Arimi SM, Kang'ethe EK, Omore A, Makokha S, Nduhiu G, Mainga AO Macharia JK. A determination of raw milk quality and the most suitable microbiological test at the milk collection level in two regions of Kenya. Int $J$ Vet Sci. 4(2):55-59.

Marzoeki AA. 1978. Penelitian peningkatan mutu dangke. Makassar [ID]: Balai Penelitian Kimia Departemen Perindustrian.

Mukhlisah AN. 2017. Kualitas kimia, fisik dan cemaran mikroba dangke sebagai respon terhadap perbedaan suhu pemanasan dan konsentrasi papain. [tesis]. Bogor (ID): Institut Pertanian Bogor.

Panesar PS, Kennedy JF, Gandhi DN, Bunko K. 2007. Bioutilisation of whey for lactic acid production. F Chem. 105:1-14.

Vinderola CG, Gueimonde M, Delgado T, Reinheimer JA de los Reyes - Gavilan CG. 2000. Characteristics carbonated fermented milk and survival of probiotik bacteria. Int Dairy J. 10:213-220. 